\title{
Understanding energy demand in Kuwaiti villas: Findings from a quantitative household survey
}

\author{
Badria Jaffar ${ }^{1}$, Tadj Oreszczyn, Rokia Raslan, Alex Summerfield
}

UCL Energy Institute, 14 Upper Woburn Place, London, WC1H 0NN, England, United Kingdom

\section{ABSTRACT}

Residential buildings in Kuwait account for almost $60 \%$ of the country's national electrical power generated, considerably greater than all other sectors or building types. This paper identifies key drivers of energy use in Kuwaiti villas based on a survey of 250 households undertaken throughout the six districts of Kuwait. The survey consists of a cross-sectional intervieweradministered questionnaire designed to gather detailed information about building physical characteristics, occupants' socio-demographic background and energy-use behaviours. Survey data is analysed using both statistical descriptive methods and multiple linear regression analysis to identify key determinants of energy consumption in a sample of Kuwaiti villas. Analysis indicates that an occupant driven cooling behaviour (air-conditioning thermostat temperature set points) is the major driver of energy use, followed by the number of rooms and the number of occupants. Together, such drivers significantly explain $32 \%$ of the variability in energy consumption Survey findings provide descriptive information about Kuwaiti households and insights into the key drivers of energy use to better inform further research and policy interventions in this field.

Keywords: household survey; residential energy demand; Kuwait; energy efficiency policy

${ }^{1}$ Corresponding author.

Tel: +44 790010 4555, +96590010989

Email address: b.Jaffar@ucl.ac.uk, b_jaffar@hotmail.com 


\section{Introduction}

The energy consumption of the Kuwaiti residential building sector is amongst the highest (per capita) in the world [1]. Residential energy use accounts for almost $60 \%$ of the country's national electrical power generated, considerably greater than all other sectors or building types [2]. The rapidly rising consumption associated with this sector is presenting serious energy security challenges for the Kuwaiti government, especially in light of the country's growing population and demand for housing [1, 3, 4]. In its latest National Development Plan (2015-2020), the Kuwaiti government announced plans to construct 45,000 new units - largely in the form of villas - by 2020 [5]. Although such ambitious housing projects are essential to meet the demands of a growing population they require significant additional production of electricity, especially as current installed capacity $(14,702 \mathrm{MW})$ is very close to peak demand (11,220 MW) [2]. This is particularly challenging as power generation is primarily oil-based and rising electricity demand will increasingly undermine the country's hydrocarbon export capacity and national income [6].

Energy efficiency policy interventions to control wasteful residential consumption are therefore essential. To effectively plan and implement such interventions a thorough understanding of the factors that drive household energy use is needed [7, 8, 9]. In Kuwait however, despite the magnitude of residential energy use, there is very limited data and research available in regards to characteristics of the housing stock, its fabric, energy consuming equipment, the disaggregation of energy use, and occupants demand for services. No detailed household survey describing the composition of the national housing stock, dwelling sizes, form and fabric characteristics, building services and appliances used, thermal characteristics and energy use, has been published to date. Building census data from various government agencies provide only limited information regarding dwelling type, count and year of build. Similarly, although a mandatory Energy Conservation Code of Practice for Buildings has been enforced since 1983, there is very little evidence of its impact in practice $[6,10]$.

To better assess the potential for efficiency improvements and demand reduction in Kuwaiti homes, a comprehensive household survey was undertaken in March 2015. The survey aimed to gather and analyse data describing physical and social characteristics of Kuwaiti homes and provide insight into key drivers of domestic energy use. Information about household socio-demographic characteristics, building form and fabric characteristics, space conditioning and water usage, lighting and electrical appliances, and electricity consumption was collected using a cross-sectional interviewer-administered questionnaire from a sample of 250 homeowners/household representatives throughout the six districts of Kuwait.

The survey has made two important contributions to the residential energy demand research field in Kuwait:

1. It represents a novel attempt to develop a comprehensive information base about the physical and social characteristics of Kuwaiti villas at a national level (about which published data is virtually non-existent.)

2. It provides insight into potential drivers of energy use in Kuwaiti villas to better inform future research and policy developments in this field. 


\section{Literature review}

\subsection{Residential energy consumption in Kuwait: causes, concerns and interventions}

Following the discovery of oil in Kuwait in 1938, the state entered an exceptional period of economic development and wealth that significantly impacted the residential building sector and its energy use [11]. Today the residential building stock consists primarily of large villas and smaller flats in mid-high rise apartment buildings (table 1). More than $80 \%$ of Kuwaiti nationals live in villas [12] of which there are two main types: government and private. Government villas are designed and built by the Public Authority for Housing Welfare (PAHW - the agency responsible for setting and implementing national housing policies), while private villas are often partly financed by the PHAW but commissioned by the homeowner. Mid-high rise apartment buildings mainly house the expatriate population, which reside in Kuwait on a temporary basis and are not normally allowed to own property. This study focuses on villas as they account for a significantly greater portion of electricity use compared to flats (table 2), are the main housing type for Kuwaiti nationals, and constitute the bulk of future PAHW housing projects.

A number of factors have contributed to the high electricity consumption by residential villas in Kuwait. These include the government's generous welfare and energy subsidy program, a rapid growth in the population (with an average annual growth rate of $3.1 \%$ [5]), municipality building codes progressively allowing for an increase in dwelling sizes (in 1996, 2002, and 2012), and the country's harsh summer climatic conditions (with average temperatures of $38^{\circ} \mathrm{C}$, and maximum temperatures reaching higher than $\left.50^{\circ} \mathrm{C}\right)[6,11,13,14]$. The energy subsidy programme facilitates high energy use consumer behaviour and the air conditioning of large homes designed with little consideration of energy efficiency [4, 13, 14]. The Energy Subsidy Programme was established in 1962, and currently subsidises $95 \%$ of the cost of energy to the final consumer. Residential consumers are charged a rate of KD $0.002 / \mathrm{kWh}$ (equivalent to $\$ 0.01$ at the time of writing) of the electricity generation cost of $\mathrm{KD} 0.047 / \mathrm{kWh}$ (equivalent to $\$ 0.16$ ); a rate that has remained unchanged for over 50 years [6].

Recognizing the need to improve energy efficiency, the Kuwait Ministry of Electricity and Water (MEW) has, since 1983, enforced a mandatory Energy Conservation Code applicable to all new and renovated buildings [15]. This code, developed by the Kuwait Institute for Scientific Research (KISR) for the MEW, set minimum thermal insulation requirements for walls, roof, columns and glazing as well as peak power guidelines for air-conditioning units [15]. Although researchers at KISR estimate that a building constructed in full compliance with the 1983 code requires $40 \%$ less cooling [10], such estimations are based on modelling-based studies and little evidence of the code's impact exists in practice $[6,10,11]$. Similarly, despite changes in design and construction technology, and developments in building simulation software, the 1983 code was only updated in 2010 and again in 2014 to allow for more stringent guidelines.

Little organised, coherent, and accessible household-level data is available about the Kuwaiti residential building stock and its energy use. No national survey describing stock composition, dwelling sizes, form and fabric characteristics, building services, appliance ownership, thermal characteristics and performance, and energy billing data has been published to date. Only basic 
information about dwelling type, count, and year of build can be gathered from national statistics data published by the Public Authority for Civil Information (PACI) and building archival records from Kuwait's Central Statistical Bureau (CSB).

Table 1: Number of residential buildings and units in Kuwait, 2013

\begin{tabular}{|c|c|c|c|c|c|}
\hline \multicolumn{2}{|c|}{ Villas } & \multicolumn{2}{|c|}{ Flats } & \multirow{2}{*}{$\begin{array}{c}\text { courtyard } \\
\text { houses }\end{array}$} & \multirow[t]{2}{*}{ Palaces } \\
\hline Government & Private & Government & Private & & \\
\hline $\begin{array}{c}56,536 \\
(19 \%)\end{array}$ & $\begin{array}{c}49,228 \\
(17 \%)\end{array}$ & $\begin{array}{c}1088 \\
(0.4 \%)\end{array}$ & $\begin{array}{c}169,727 \\
(57 \%)\end{array}$ & & \\
\hline \multicolumn{2}{|c|}{105,764} & \multicolumn{2}{|c|}{170,815} & $\begin{array}{c}20,984 \\
(7 \%)\end{array}$ & $\begin{array}{c}47 \\
(0 \%)\end{array}$ \\
\hline
\end{tabular}

Source: [16]

Note: the percentage of the total stock for each dwelling type is reported in parentheses.

Table 2: Average energy use by flats and villas in Kuwait

\begin{tabular}{|c|c|c|c|c|c|c|}
\hline \multicolumn{5}{|c|}{ KUWAIT } & \multicolumn{2}{|c|}{ UK (2013) } \\
\hline \multirow[b]{2}{*}{$\begin{array}{c}\text { Dwelling } \\
\text { type }\end{array}$} & \multirow[b]{2}{*}{$\begin{array}{c}\text { Number } \\
\text { of } \\
\text { dwellings }\end{array}$} & \multicolumn{3}{|c|}{ Electricity use (2009) } & \multirow[b]{2}{*}{$\begin{array}{l}\text { Average kWh/ } \\
\text { dwelling/ } \\
\text { annum }\end{array}$} & \multirow[b]{2}{*}{$\begin{array}{c}\text { Average kWh/ } \\
\text { m²/ }^{2} \\
\text { dwelling/ } \\
\text { annum }\end{array}$} \\
\hline & & $\begin{array}{l}\text { Percentage } \\
\text { of total } \\
\text { residential } \\
\text { energy use }\end{array}$ & $\begin{array}{l}\text { Average } \\
\text { kWh/ } \\
\text { dwelling/ } \\
\text { annum }\end{array}$ & $\begin{array}{c}\text { Average } \\
\mathrm{kWh} / \mathrm{m}^{2} / \\
\text { dwelling/ } \\
\text { annum }\end{array}$ & & \\
\hline Villas & 105,764 & $88 \%$ & 145,444 & 264 & \multirow{2}{*}{$\begin{array}{c}\text { 4,170: electricity } \\
\text { 14,829: gas } \\
\text { Total: } 18,999\end{array}$} & \multirow[t]{2}{*}{209} \\
\hline Flats & 170,815 & $12 \%$ & 20,278 & 127 & & \\
\hline
\end{tabular}

Source: $[17,18]$

Note: Villas include both private villas and government villas. Average $\mathrm{kWh} / \mathrm{m}^{2} / \mathrm{dwelling}$ for villas in Kuwait has been calculated based on an approximate floor area of $550 \mathrm{~m}^{2}$, and for flats $160 \mathrm{~m}^{2}$.Average $\mathrm{kWh} / \mathrm{m}^{2} / \mathrm{dwelling}$ in the UK has been calculated based on an average dwelling size of $91 \mathrm{~m}^{2}[19]$.

\subsection{Drivers of residential energy use}

A number of studies have been undertaken internationally in the field of residential energy demand, especially following the oil price adjustments that took place in the 1970's. Such studies have, through various methods, attempted to better understand the sector's energy use profile and the drivers that may influence this. Researchers have examined and established the impact of building physical factors on energy consumption including building size, age, and thermal and system performance $[7,8,20,21,22]$. Studies have found that such factors alone explain about $39 \%$ [7] and $42 \%$ [20] of the variability in domestic energy use. Among such factors, building size and type were found to be the most important in predicting energy demand [7, 20, 23, 24, 25]. Building age however is found in the literature to have different effects on energy consumption; some studies report a negative association between building age and energy use (due to improved building efficiency standards) $[14,26]$, while others report a positive relationship (due to an increase in the penetration of high-consuming appliances) [25], or no significant effect [8].

In recent years, interest in the role of occupants (socio-demographic characteristics and behaviour) and their impact on energy use in buildings has increased [20, 22, 27, 28, 29, 30]. In regards to household socio-demographic characteristics, several studies suggest that household income is an important driver of energy use [20,28, 31], with higher income households more likely 
to have higher energy consumption levels. Another noted driver is household size which was found to be positively correlated with energy use [7, 32, 33]. In regards to household age however, the evidence is mixed; some studies have found older households tend to consume more energy than younger households [20,26,34], while others have found the opposite effect [35] or no effect at all [28]. With regards to occupant behaviour, this has largely been measured in terms of occupant preferences in space conditioning and temperature settings and set points $[13,20,22,29]$ as well as presence at home [30]. Although many studies [13, 20, 22, 29] have documented the important effect of occupant behaviour on energy consumption, the extent of this remains relatively unclear $[7,20]$. This is, in part, due to the complexity associated with measuring and assessing behaviour, which in turn is driven by various factors such as income, energy tariffs, thermal quality of the building and climate $[7,20,22,29]$.

\section{Survey description}

\subsection{Survey questionnaire}

The household survey of this study consists of a standard questionnaire with a number of close-ended questions, drafted specifically to fit the context of Kuwait. The questionnaire has attempted to collect data about both building and occupant-related characteristics and is divided into five parts (table 3). In developing the survey, a number of relevant questionnaires were reviewed. These included the Carbon Reduction in Buildings (CaRB) questionnaire [36], the UK Department of Energy and Climate Change Energy Follow Up Survey (EFUS) questionnaire [37], University College London's Residential Energy Use in Oman household questionnaire [38], and the US Department of Energy and Energy Information Administration Residential Energy Consumption questionnaire [39]. The source questionnaire (drafted in English) was translated into the Arabic language, using a mixed translation technique, to ensure all respondents are able to understand the questions. 
Table 3-Questionnaire structure

\begin{tabular}{|c|c|c|}
\hline Section & Description of questions & Rationale \\
\hline $\begin{array}{l}\text { 1. Household socio- } \\
\text { demographic } \\
\text { profile }\end{array}$ & $\begin{array}{l}\text { Villa tenure; main householder employment } \\
\text { and education status; household size and age. }\end{array}$ & $\begin{array}{l}\text { This data sets the basic socio-demographic } \\
\text { context and provides key information for } \\
\text { interpreting the survey results. }\end{array}$ \\
\hline $\begin{array}{l}\text { 2. Building form and } \\
\text { fabric } \\
\text { characteristics }\end{array}$ & $\begin{array}{l}\text { Construction date; villa type; built up area } \\
\left(\mathrm{m}^{2}\right) \text {; number of floors; number of unused } \\
\text { rooms; refurbishment works; level of wall and } \\
\text { roof insulation; glazing type; window shading; } \\
\text { building cladding material. }\end{array}$ & $\begin{array}{l}\text { This data enables an understanding of the } \\
\text { physical characteristics of the villa stock to } \\
\text { better determine its overall efficiency and } \\
\text { potential costs and benefits of fabric } \\
\text { improvements. }\end{array}$ \\
\hline $\begin{array}{l}\text { 3. Space } \\
\text { conditioning and } \\
\text { domestic hot } \\
\text { water use }\end{array}$ & $\begin{array}{l}\text { Air-conditioning }(\mathrm{AC}) \text { type and age; } \mathrm{AC} \text { use } \\
\text { throughout the year; number and cooling } \\
\text { capacity of AC units; number of rooms cooled; } \\
\text { AC thermostat settings and control; AC } \\
\text { maintenance; Space heating; occupant } \\
\text { thermal comfort during different seasons and } \\
\text { control of this; domestic hot water (DHW) } \\
\text { type; DHW fuel; DHW control. }\end{array}$ & $\begin{array}{l}\text { This data allows for a better understanding of } \\
\text { building system characteristics, performance } \\
\text { and efficiency, as well as occupants demand } \\
\text { for and interaction with these. }\end{array}$ \\
\hline $\begin{array}{l}\text { 4. Lighting and } \\
\text { appliances }\end{array}$ & $\begin{array}{l}\text { Main lighting type; natural daylight quality; } \\
\text { number of electrical appliances and their } \\
\text { frequency of use. }\end{array}$ & $\begin{array}{l}\text { This data enables an understanding of costs } \\
\text { and benefits of potential appliance efficiency } \\
\text { schemes. }\end{array}$ \\
\hline $\begin{array}{l}\text { 5. Electricity } \\
\text { consumption }\end{array}$ & $\begin{array}{l}\text { Estimated annual electricity bill in KWD; } \\
\text { electricity payment interval; awareness of } \\
\text { online payment options; concern about } \\
\text { energy use and payment. }\end{array}$ & $\begin{array}{l}\text { This data enables the calculation of energy } \\
\text { consumption in kWh and the examination of } \\
\text { relationships between energy use and other } \\
\text { variables measured by the survey. }\end{array}$ \\
\hline
\end{tabular}

\subsection{Respondent sampling strategy and sampling bias}

\subsubsection{Constraints in conducting residential energy related research in Kuwait}

Considering the nature of this study and the social norms within Kuwait, the following constraints were accounted for when designing the respondent sampling strategy:

1. Restricted access to homes due to the novelty of the research approach in the region.

2. Lack of willingness to share data due to great privacy concerns.

3. Cultural restrictions associated with conducting interviews at private residences.

Such constraints played a central role in determining the methodology for sample selection as explained below.

\subsubsection{Methodology for sample selection}

The survey target population was defined as 'homeowners/household representatives living in single family detached villas in Kuwait'. Based on figures from the Public Authority for Civil Information [16], there are 105,764 villas and approximately the same number of homeowners to 
survey. An adequate sample size of 250 respondents was calculated based on the confidence interval approach, using a confidence level of $90 \%$ and an acceptable sampling error of $5 \%$, both deemed to be appropriate for the indicative nature of this survey [40].

To ensure the sample consists of households throughout the six districts of Kuwait the target population was then proportionally stratified by geographical region (based on the number of villa in each district). Several residential neighborhoods within each district were randomly selected. Rather than administrating surveys at individual household addresses (for reasons mentioned above), questionnaires were administered at residential cooperative society complexes (co-op's) within the randomly selected neighborhoods. Co-ops complexes in Kuwait are central and integral public spaces well distributed within residential neighborhood that include facilities such as medical clinic, post office, subsidized grocery store, electricity bill payment office etc. Membership in a neighborhood's co-op and use of its services (such as medical clinic) is exclusive for residents of that neighborhood that have a registered address within that area. Data collection was then performed through face-to-face interviews, with the aid 12 trained interview personnel. Interviewers administrating the survey at the residential co-op's were required to ask potential respondents two screener questions before starting the survey 1 ) to determine if they lived in this district, 2) if they are a homeowner or a key household representative. A thorough interviewer briefing session ensured all interviewers were aware of questionnaire meaning, purpose, and content.

\section{Data analysis}

Data analysis consisted of a descriptive analysis and multiple linear regression analysis using SPSS (version 22) [41]. Such an analysis conveys characteristics and relationships within this large sample of Kuwaiti villas. Descriptive analysis involved summarising the data set to illustrate key characteristics about the sample, its energy use, and representativeness in relation to the wider population. Multiple regression analysis involved assessing the contributions of the different predictor variables on energy consumption. Variables were input into the model based on a screening process to determine which had a significant relationship with energy use. A correlation matrix was created using Pearson's correlation coefficient to highlight the strength of the relationship with predictor variables measured at the numeric level (number of rooms, number of occupants, number of appliances, AC thermostat setting). For variables measured the categorical rank order level (villa size, age, and household income) Spearman's rank correlation coefficient was used, and for variables measured at the categorical nominal level (villa type, tenure, type of families, education status, AC type, lighting type, glazing type, and insulation) the one-way Anova test was used to detect any differences between categories of a variable. All variables measured at the categoric level were transformed before being entered into the model; dwelling age (initially 6 categories) was transformed into a dichotomous variable with values grouped into post and pre 1983. For dwelling size and household income dummy variables were used. The regression method utilised was forced entry regression, in which all predictors are forced into the model simultaneously. 


\section{5. $\quad$ Results}

Questionnaire results are presented in two main parts: 1) survey data description and 2) multiple regression analysis.

\subsection{Survey data description}

\subsubsection{Survey sample characteristics in relation to national statistics data}

In an attempt to determine the representativeness of the survey sample, a brief comparison of the survey data with available, published national statistics data (relating to the villa stock) was made. This process was a useful interim step for checking the validation of the methodology and survey sample representativeness.

As illustrated in table 4 the survey sample appears to be fairly representative of households and villas in Kuwait with regards to villa type, villa age, household size, and household monthly income. With regards to annual electricity consumption however, the survey sample had a significantly higher average than that found in national statistics, and responses had a wide range in value. Possible explanations for this include:

- The likelihood that a number of respondents arbitrarily quoted a total water and electricity utility bill, rather than just an electricity bill. This is due to the fact that in Kuwait the current system requires that householders pay electricity and water bills simultaneously.

- A significant lack of awareness among households in regards to their electricity consumption, particularly as only $65 \%$ of the sample responded to this question. Very low electricity tariffs and slack requirements from the MEW for regular payments are likely to have contributed to this lack of awareness. Furthermore, as outlined in section 5.1.6 below, many households did not make regular yearly payments.

- The national average is based on consumption measured in 2009, six years prior to conducting this survey. Villa sizes are likely to have increased since 2009 especially following allowances for this by Kuwait Municipality in 2012 (a villa's total built up area is now $210 \%$ of its plot size - a rise of $40 \%$ from 1996). Similarly, household size per villa is also expected to have risen considering the very rapid growth in Kuwait's population.

To improve the quality of this data for regression analysis in section 5.2, national energy consumption data was overlaid over the sample's data to identify potential outliers. 
Table 4 - Sample characteristics in relation to national statistics

\begin{tabular}{|c|c|c|}
\hline & Survey sample & National villa stock \\
\hline Villa type & $\begin{array}{c}\text { Government villas: } 48 \% \\
\text { Private design/built villas: } 52 \%\end{array}$ & $\begin{array}{c}\text { Government villas: } 54 \% \\
\text { Private design/built villas: } 46 \%\end{array}$ \\
\hline Villa age & $\begin{array}{c}\text { Before 1960: } 1 \% \\
\text { 1960-1983: } 18 \% \\
\text { 1984-1995: } 28 \% \\
1996-2009: 45 \% \\
2010-2014: 8 \%\end{array}$ & $\begin{array}{c}\text { Before 1960:1\% } \\
\text { 1960-1983: } 19 \% \\
\text { 1984-1995: } 28 \% \\
\text { 1996-2009: 43\% } \\
2010-2014: 9 \%\end{array}$ \\
\hline $\begin{array}{c}\text { Household size } \\
\text { (number of occupants) }\end{array}$ & 9.3 & 8.0 \\
\hline $\begin{array}{l}\text { Monthly household income } \\
\text { (KWD/month) }\end{array}$ & $\begin{array}{c}\text { Below } 1000 \text { KWD }(\$ 3330): 2 \% \\
1000-2500(\$ 3330-\$ 8326): 43 \% \\
2501-3500(\$ 8329-\$ 11656): 30 \% \\
\text { Greater than } 3500 \text { (\$11656):24\% }\end{array}$ & $\begin{array}{l}2200 \mathrm{KWD} \\
(\$ 7327)\end{array}$ \\
\hline $\begin{array}{l}\text { Average annual electricity } \\
\text { bill and energy consumption }\end{array}$ & $\begin{array}{l}\text { 801KWD (\$2668)/annum/villa } \\
400,433 \text { kWh/annum/villa }\end{array}$ & $\begin{array}{c}\text { 291KWD (\$969) /annum/villa } \\
145,444 \text { kWh/annum/villa }\end{array}$ \\
\hline
\end{tabular}

Sources: National data - PACI [16]

Annual electricity data based on a sample of 50,000 villas in 2009 - MEW [17]

Note - Conversions from Kuwaiti Dinar (KWD) to US dollar (\$) are based on the exchange rate at the time of writing: 1 KWD=\$3.33)

\subsubsection{Household socio-demographic profile}

Table 5 presents details of the survey sample's socio-demographic profile. As shown, the main householder is fully employed and university educated in more than half of the survey sample. The average total monthly household income is between 1000-2500 KWD (\$3330-\$8326) with households living in government villas tending to have lower incomes than those living in private bought/built villas. The majority of households consist of nuclear families (66\%), while a smaller portion consists of larger extended families (30\%). The average household size (number of occupants) is quite large with approximately 7.8 family members and 1.5 staff members per household. Most households (70\%) have at least 1 or more staff members, while a smaller proportion (30\%) have no staff at all. On average, most households have family members aged between 5 to 45, and household staff aged between 26-35.

Table 5 - Household socio-demographic profile

\begin{tabular}{|l|l|}
\hline \multicolumn{1}{|c|}{ Variables } & \multicolumn{1}{c|}{ Survey responses } \\
\hline Villa tenure & Owned:92\%, rented:8\%, \\
\hline Main householder employment & Full time: 66\%, part time:19\%, unemployed/retired:15\% \\
\hline Main householder education & $\begin{array}{l}\text { University post-graduate:4\%, university undergraduate: 62\%, high school:31\%, } \\
\text { elementary:4\% }\end{array}$ \\
\hline Family type living in villa & Nuclear family:66\%, extended family: 30\%, multiple families:4\% \\
\hline Number of occupants & Mean: 9.3 \\
\hline Family members age groups & $\begin{array}{l}0-4: 30 \%, 4-18: 64 \%, 18-25: 75 \%, 26-35: 72 \%, 36-45: 62 \%, 46-55: 56 \%, 56-65: 26 \%, \\
\text { over 65:8\% }\end{array}$ \\
\hline Staff members age groups & $19-25: 23 \%, 26-35: 44 \%, 36-45: 23 \%, 45-55: 5 \%$ \\
\hline Total monthly household income (KWD) & $\begin{array}{l}\text { Less than 1000 KWD (\$3330):2\%, 1000-2500KWD (\$3330-\$8326):43\%, } \\
2501-3500 \text { KWD (\$8329-\$11656):30\%, greater than 3500 KWD (\$11656):24\% }\end{array}$ \\
\hline
\end{tabular}

\subsubsection{Building form and fabric characteristics}

Table 6 presents details of the survey sample's villa form and fabric characteristics. Most villas are large in size (area), with $44 \%$ of households living in $651-750 \mathrm{~m}^{2}$ sized villas and $15 \%$ of 
households in villas greater than $750 \mathrm{~m}^{2}$. Overall, $58 \%$ are three floors or more in height. The average number of rooms per villa is 23 , including many bedrooms, bathrooms, and living rooms. Privately built villas were generally larger than government villas in floor area, number of rooms and number of floors.

Almost half of the households have undertaken some form of refurbishment works, the vast majority of which consists of vertical extensions to add additional space. Such refurbishments are likely to be driven by Municipality building codes continuously allowing for an increase in building size with time (1996, 2002, and 2012). Overall, newer villas are slightly larger than older villas (in the number of rooms and floor area), although no statistically significant association was found between dwelling size and age (possibly due to many older dwellings increasing in size due to later refurbishments). When considering the number of occupants in relation to the total number of rooms, a positive correlation is found between the two (Pearson's $r=0.380, p$-value $=0.000$ ), although the relationship is relatively weak. This is in line with the finding that a significant number of households (20\%) have several completely unused rooms. Similarly, no significant relationship was found between the number of occupants and total floor area.

With regards to the building fabric, although most households reported that their villas are well or adequately insulated, a trend towards better levels of insulation was found among newer villas in comparison to those built before the 1983 energy conservation code. It was also found that newer villas tend to have double glazing, triple glazing, or solar reflective glazing, rather than single glazing. Almost all households shade their windows either with internal curtains or blinds or external aluminum shutters. The main cladding material used in villas was found to be concrete bricks and blocks, followed by sigma - a cement-based mixture and stone.

Table 6 - Building form and fabric characteristics

\begin{tabular}{|l|l|}
\hline \multicolumn{1}{|c|}{ Variables } & \multicolumn{1}{|c|}{ Survey responses } \\
\hline Villa age & $\begin{array}{l}\text { Before 1960: 1\%, 1960-1983:18\%, 1984-1995:28\%, 1996-2009:44\%, 2010- } \\
2014: 9 \%\end{array}$ \\
\hline Villa type & Government:48\%, private:52\% \\
\hline Villa size $\left(\mathrm{m}^{2}\right)$ & $\begin{array}{l}\text { Less than 350:1\%, 351-450:2\%, 451-550:15\%, 551-650:23\%, 651-750:44\%, } \\
751-850: 1 \%,>1000: 14 \%\end{array}$ \\
\hline Number of floors & 1 floor:3\%, 2 floors:39\%, 3 floors:46\%, <4 floors:12\% \\
\hline Number of rooms & $\begin{array}{l}\text { Mean number of rooms per villa: } 23 . \\
\text { Mean number of rooms by type - Bedrooms: 7.2, staff bedrooms 1.8, } \\
\text { bathrooms: } 5.4, \text { living rooms: } 2.6, \text { dining rooms 1.4, washing rooms: } 1.2, \\
\text { kitchen:2.1, diwaniya:1.1, basement:0.5, Office:0.3 }\end{array}$ \\
\hline Unused rooms & Yes: $21 \%$, no:79\% \\
\hline Number of unused rooms & $1-2: 64 \%, 3-4: 30 \%,>5: 6 \%$ \\
\hline Refurbishment works & Yes: 49\%, no:51\% \\
\hline Type of refurbishment & $\begin{array}{l}\text { Vertical extension: 41\%, horizontal extension:12\%, resealing windows:20\%, } \\
\text { insulation walls: } 6 \%, \text { upgrading AC equipment:1\%, upgrading hot water tank:9\% }\end{array}$ \\
\hline Wall insulation & $\begin{array}{l}\text { Well insulated:75\%, adequately insulated:20\% poorly insulated:2\% not } \\
\text { insulated:3\% }\end{array}$ \\
\hline Roof insulation & $\begin{array}{l}\text { Well insulated:71\%, adequately insulated:23\% poorly insulated:2\% not } \\
\text { insulated:3\% }\end{array}$ \\
\hline Glazing & Single:30\%, double:31\%, triple:7\%, solar reflective:32\% \\
\hline Window shading & External shutters:33\%, internal curtains:62\%, overhangs:4\%, no shading:1\% \\
\hline External cladding & Concrete blocks or bricks:55\%, sigma:24\%, stone:20\%, glass:1\% \\
\hline
\end{tabular}




\subsubsection{Space conditioning and domestic hot water use}

Table 7 presents details of the survey sample space conditioning and domestic hot water use. Findings show that all households use air-conditioning to cool their homes. Centralized AC systems are the primary method of cooling with $66 \%$ of the sample using a centralized system, $8 \%$ a mixed system (central and split units), and $26 \%$ split-units only. Almost all respondents (94\%) with centralized AC use this method to cool their entire villa, while a smaller portion (74\%) of respondents with split units use this method to do the same. The majority $(44 \%)$ of households cool their villas for eight months of the year mainly from March to October, even though external conditions are moderate in March, see figure 1.

Most households with centralized AC have either 5 or more direct expansion units and many do not know their cooling capacity, while households with split units have an average of 9 units, and all were aware of the unit's cooling capacity. Most respondents (43\%) have AC equipment that is more than 9 years old, and although the majority (69\%) regularly maintain their equipment once a year, a notable proportion do not (14\%). Thermostats are used by all households to control AC equipment, and the average temperature setting is found to be $21^{\circ} \mathrm{C}$ (figure 2). When villas are unoccupied for prolonged time periods (such as travel), only $54 \%$ of respondents always adjust their AC thermostat.

With regards to space heating, only $49 \%$ of households heat their villas in winter while $23 \%$ sometimes do and $28 \%$ don't. Almost all households that heat their villas use electric portable heaters as the main method of heating compared to using the air-conditioning system as a heater. Electricity is the main fuel used for domestic hot water (DHW), with roughly equal use of centralized and individual systems. Most respondents use DHW for 4 to 6 months of the year from OctoberMarch. When villas are unoccupied for prolonged time periods (e.g. while abroad during the heat of the summer), only $57 \%$ switch off their DHW.

Regarding thermal comfort, occupants reported that they tended to use non-passive control measures to cool down during summer including lowering the temperature on the thermostat and/or using additional cooling devices. Very few opted for passive responses such as taking off clothes or closing curtains. In winter however, a greater number of householders adapted passively by closing windows or putting on additional clothes.

Table 7-Space conditioning and domestic hot water use

\begin{tabular}{|l|l|}
\hline \multicolumn{1}{|c|}{ Variables } & \multicolumn{1}{c|}{ Survey responses } \\
\hline Air-conditioning (AC) system type & Central:66\%, split:26\%, mixed (central and split):8\% \\
\hline AC operation (months) & $5-6$ months:14\%, 7-8 months:68\%, 9-10 months:16\%, 11-12 months:2\% \\
\hline Number central units & $1-2: 12 \%, 3-4: 20 \%, 5-6: 25 \%$, more than $6: 25 \%$, unsure:18\% \\
\hline Number of split units & Mean:9 \\
\hline AC thermostat temperature set points & Mean: $2{ }^{\circ} \mathrm{C}$, see figure 2 \\
\hline Cooling capacity of central units (tons) & 3 or less; $10 \%, 4-10: 38 \%, 10$ or more:10\%, don't know:40\% \\
\hline Cooling capacity of split units (tons) & Less than 1: $\%, 1-2: 46 \%, 2.5$ tons or more:47\%, don't know: 3\% \\
\hline Rooms cooled by central AC & All rooms: $94 \%$, bedrooms only:6\% \\
\hline Rooms cooled by split units & All rooms: $74 \%$, staff bedrooms:9\%, external kitchen:7\%, other: $10 \%$ \\
\hline AC age (years) & $>1: 2 \% 1-3: 10 \% ; 3-6: 26 \%, 6-9: 18 \%$, more than $9: 44 \%$ \\
\hline AC maintenance interval & Once yearly:69\%, twice yearly:13\%, every two years:4\%, randomly:14\% \\
\hline $\begin{array}{l}\text { Adjusting AC settings during periods of } \\
\text { prolonged absence }\end{array}$ & Yes:54\%, somethimes:22\%, no:24\% \\
\hline Space heating during winter & Yes:49\%, somethimes:23\%, no:28\% \\
\hline Space heating system type & Portable electric heaters:91\%, AC system heating mode:9\% \\
\hline Domestic hot water (DHW) system type & Central: $52 \%$, local:46\%, mixed:2\% \\
\hline
\end{tabular}




\begin{tabular}{|l|l|}
\hline Hot water usage - months/year & $3-4: 29 \%, 5-6: 48 \%, 7-8: 20 \%, 9-10: 1 \%, 11-12: 2 \%$ \\
\hline $\begin{array}{l}\text { Switching DHW off during periods of } \\
\text { prolonged absence }\end{array}$ & Yes:14\%, sometimes:29\%, no:57\% \\
\hline Thermal comfort inside villa - summer & Cold:3\%, cool:7\%, slightly cool:8\%, neutral:73\%, slightly warm:7\% warm:2\% \\
\hline Thermal comfort outside villa-summer & Neutral:40\%, slightly warm:7\% warm:10\%, Hot:42\% \\
\hline Thermal comfort inside villa - winter & Cold:2\% cool:10\% slightly cool:16\%, neutral:68\% slightly warm:4\% \\
\hline Thermal comfort outside villa - winter & Cold:28\%, cool: $20 \%$, slightly cool:8\% neutral:42\%, slightly warm:2\% \\
\hline Strategy to cool down in summer & $\begin{array}{l}\text { Lower thermostat temp.:54\%, use extra cooling devices:19\%, open } \\
\text { windows:16\%, close curtains:5\%, remove some clothes:11\%, do nothing:44\% }\end{array}$ \\
\hline Strategy to warm up in winter & $\begin{array}{l}\text { Use heating devices:36\%, put on more clothes:27\%, close windows:28\%, } \\
\text { do nothing:53\% }\end{array}$ \\
\hline
\end{tabular}

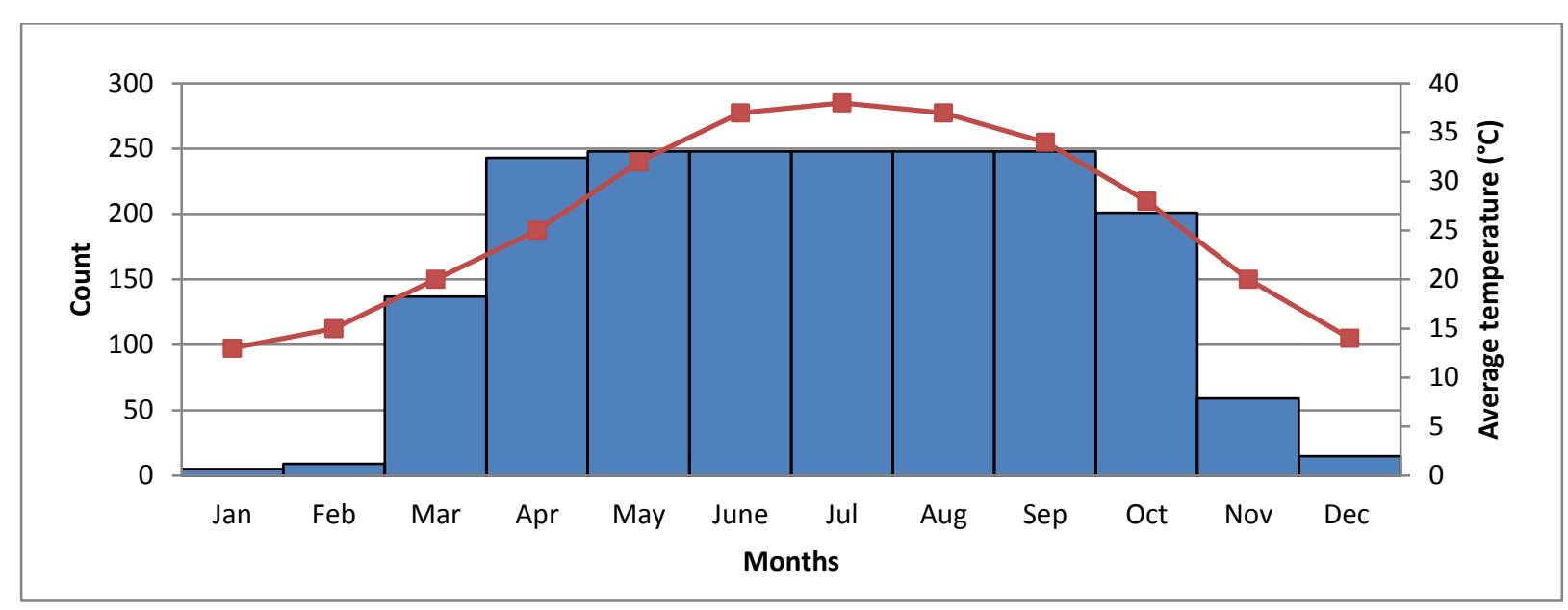

Figure 1 - Monthly AC use by survey sample and average monthly external temperature for Kuwait (sourced from Kuwait metrological centre: 1964-2015 [42])

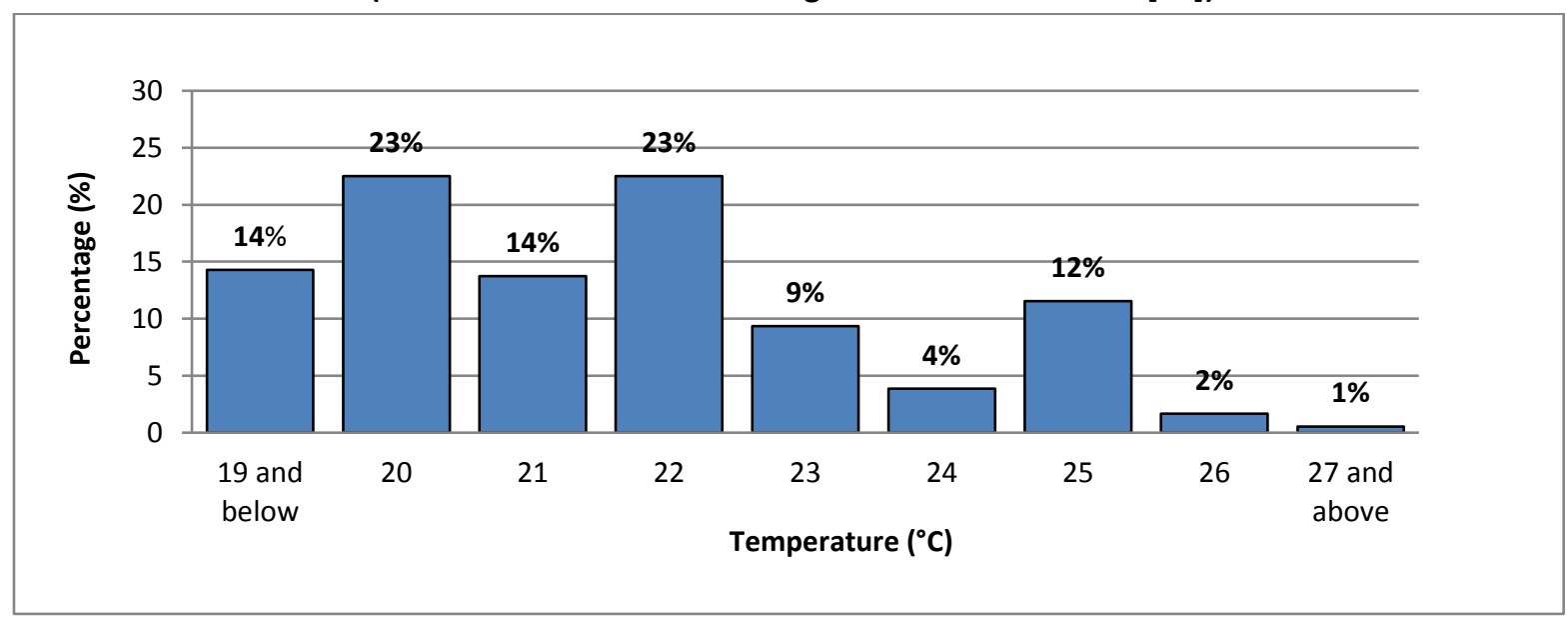

Figure 2 - AC thermostat temperature set points

\subsubsection{Lighting and appliances}

Table 8 presents the survey sample's lighting and appliance use. Most households had adopted fairly efficient lighting practices; $66 \%$ of households use energy efficient bulbs (LED or CFL), while only $23 \%$ use incandescent bulbs, and the majority of respondents (76\%) always switch lights off in unoccupied rooms.

The typical villa had approximately 32 appliances broken down by number and type in table 8. Although a positive correlation was detected between the total appliance stock and the number 
of occupants (Pearson's $r=0.406, p$-value $=0.000$ ) indicating that larger households tend to have more appliances, this relationship is moderate as several households presumably have appliances in excess of occupants needs. Similarly, although a positive correlation was also found between appliance stock and household income (Spearman's rho $=0.339, \mathrm{p}$-value $=0.000$ ), the relationship is fairly weak possibly due to the fact that low electricity tariffs may enable lower income households to afford the running costs associated with many extra appliances.

Table 8 - Lighting and appliances

\begin{tabular}{|l|l|}
\hline \multicolumn{1}{|c|}{ Variables } & \multicolumn{1}{c|}{ Survey responses } \\
\hline Main lighting type & Incandescent:24\%, florescent:19\%, LED:57\% \\
\hline Switching lights off in unoccupied rooms & Always:77\%, often:23\% \\
\hline $\begin{array}{l}\text { Appliance stock } \\
\text { (mean) }\end{array}$ & $\begin{array}{l}\text { TV:4, satellite receiver:4, fridge:3, freezer, 2, water cooler:2, } \\
\text { water pump:1, toaster: 1, kettle:2, microwave:2, electric oven: } 1, \\
\text { gas oven:1, Gas stove:2, electric stove:1, vacuum: } 2, \\
\text { washing machine:2, clothes dryer:1, games console:1 }\end{array}$ \\
\hline Washing machine usage & Daily:39\%, every other day: 29\%, every three days: $29 \%$, once a week:4\% \\
\hline Clothes dryer usage & Daily:42\%, every other day:26\%, every three days:29\%, once a week:3\% \\
\hline Vacuum usage & Daily:75\%, every other day:14\%, every three days:7\%, once a week:4\% \\
\hline
\end{tabular}

\subsubsection{Electricity consumption}

Table 9 presents details of the survey sample's electricity consumption. It was found that the majority of households pay their electricity bills once annually. This indicates the lack of importance given to payment (especially as no protocols are currently set by law). More than half the respondents were also unaware that electricity bills could be paid online. In spite of this, when asked about their level of concern for the amount of energy used and the payment made for this, almost $80 \%$ of the sample claimed they are either very concerned or concerned.

The mean annual electricity bill for households was found to be 801 KWD (\$2668)/annum $(400,433 \mathrm{kWh} /$ annum). As explained in section 5.1 .1 above this figure is likely to be influenced by some respondents reporting a total utility bill (water and electricity), as it is the norm in Kuwait to pay such bills simultaneously. To improve the quality of this data for the regression analysis, national consumption data was overlaid over the survey sample data to identify potential outliers. As less than $1 \%$ of the national villa stock consume more than $450,000 \mathrm{KWh} / \mathrm{annum}$ (900KWD or $\$ 2997$ per annum), all cases that reported consumption greater than this value (62 cases) were considered outliers, with implausible energy consumption, and removed from the sample (figures 3 ). A revised mean electricity bill was found to be $500 \mathrm{KWD}$ (\$1665)/annum (equivalent to 250,198 kWh/annum) for a total of 101 households. 
Table 9 - Electricity consumption

\begin{tabular}{|l|l|}
\hline \multicolumn{1}{|c|}{ Variables } & \multicolumn{1}{c|}{ Survey responses } \\
\hline Electricity bill payment interval & $\begin{array}{l}\text { 3 months or less:25\%, every 6 months:7\%, every 12 months:31\%, more than } \\
12 \text { months:10\%, when prompted by MEW:7\%, on't know:20\% }\end{array}$ \\
\hline Average electricity bill KWD/annum/villa & $\begin{array}{l}\text { Mean: 801 KWD (equivalent to \$2668 at the time of writing) } \\
\text { (based on a response by 65\% of the sample) }\end{array}$ \\
\hline Awareness of online bill payment option & Yes:41\%, no:59\% \\
\hline Concern about energy consumption & Very concerned:48\%, concerned:30\%, neutral:11\%, unconcerned:11\% \\
\hline Concern about energy payment & Very concerned:44\%, concerned:35\%, neutral:10\%, unconcerned:11\% \\
\hline
\end{tabular}

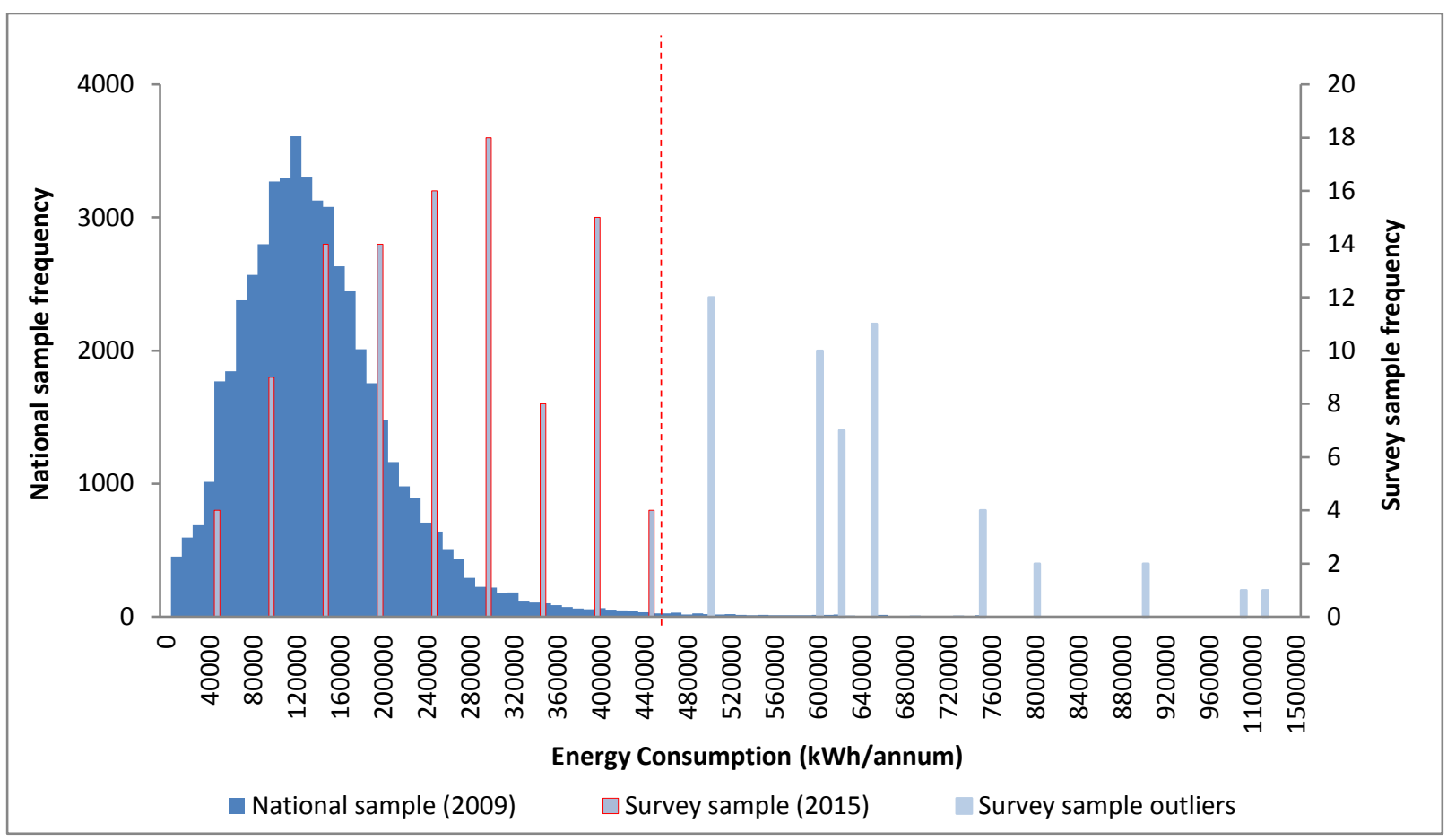

Figure 3 - Villa yearly electricity consumption: National sample vs. Survey sample Note: Survey sample responses greater than $450,000 \mathrm{kWh} /$ annum were considered outliers

\subsection{Regression analysis}

A multiple regression was undertaken in an aim to determine how much of the variance in energy consumption (the dependant variable) could be explained by different predictor variables. The analysis was performed on two sets of annual electricity consumption data measured in $\mathrm{kWh}$ :

1) Original consumption data with outliers (163 cases),

2) Consumption data with outliers removed based on the national statistics (101 responses)

All predictor variables were screened before being input into the model to determine whether they had significant relationships with electricity consumption data. Table 10 illustrates the six predictor variables found to be significantly correlated with energy consumption and thus input into the model. Figure 4 presents box plots to further illustrate the nature of these relationships. As shown, electricity consumption tended to increase as the number of rooms, number of occupants, villa size (total floor area), and household income increased. In contrast, electricity consumption generally decreased as AC thermostat temperature set points and villa age increased. 
Table 10 - Variable description and correlations with electricity consumption data

\begin{tabular}{|c|c|c|c|}
\hline \multirow[b]{2}{*}{ Independent variables } & \multirow[b]{2}{*}{ Description } & \multicolumn{2}{|c|}{ Correlation with electricity consumption data } \\
\hline & & $\begin{array}{l}\text { Original data: with outliers } \\
\text { (163 cases) }\end{array}$ & $\begin{array}{l}\text { Adjusted data: without } \\
\text { outliers (101 cases) }\end{array}$ \\
\hline Villa age & $\begin{array}{c}\text { Categorical rank-order } \\
\text { (6 categories) }\end{array}$ & No correlation & $\begin{array}{c}\text { Spearman's rho }=-0.284, \\
p \text {-value }=0.004\end{array}$ \\
\hline Number of rooms & Continuous & $\begin{array}{c}\text { Pearson's } r=0.208 \\
p \text {-value }=0.004\end{array}$ & $\begin{array}{c}\text { Pearson's } r=0.421 \\
p \text {-value }=0.000\end{array}$ \\
\hline Villa size (total floor area) & $\begin{array}{c}\text { Categorical rank-order } \\
\text { (9 categories) }\end{array}$ & No correlation & $\begin{array}{c}\text { Spearman's rho }=0.266 \\
p \text {-value }=0.007\end{array}$ \\
\hline Number of occupants & Continuous & $\begin{array}{c}\text { Pearson's } r=0.206 \\
p \text {-value }=0.005\end{array}$ & $\begin{array}{c}\text { Pearson's } r=0.269, \\
p \text {-value }=0.006\end{array}$ \\
\hline Household income & $\begin{array}{c}\text { Categorical rank-order } \\
\text { (4 categories) }\end{array}$ & No correlation & $\begin{array}{c}\text { Spearman's rho }=0.295, \\
\text { p-value }=0.003\end{array}$ \\
\hline $\begin{array}{c}\text { AC thermostat } \\
\text { temperature setting }\end{array}$ & Continuous & $\begin{array}{c}\text { Pearson's } r=-0.174, \\
p \text {-value }=0.046\end{array}$ & $\begin{array}{c}\text { Pearson's } r=-0.348, \\
p \text {-value }=0.003\end{array}$ \\
\hline
\end{tabular}

Note: Correlations are significant at the 0.01 level 


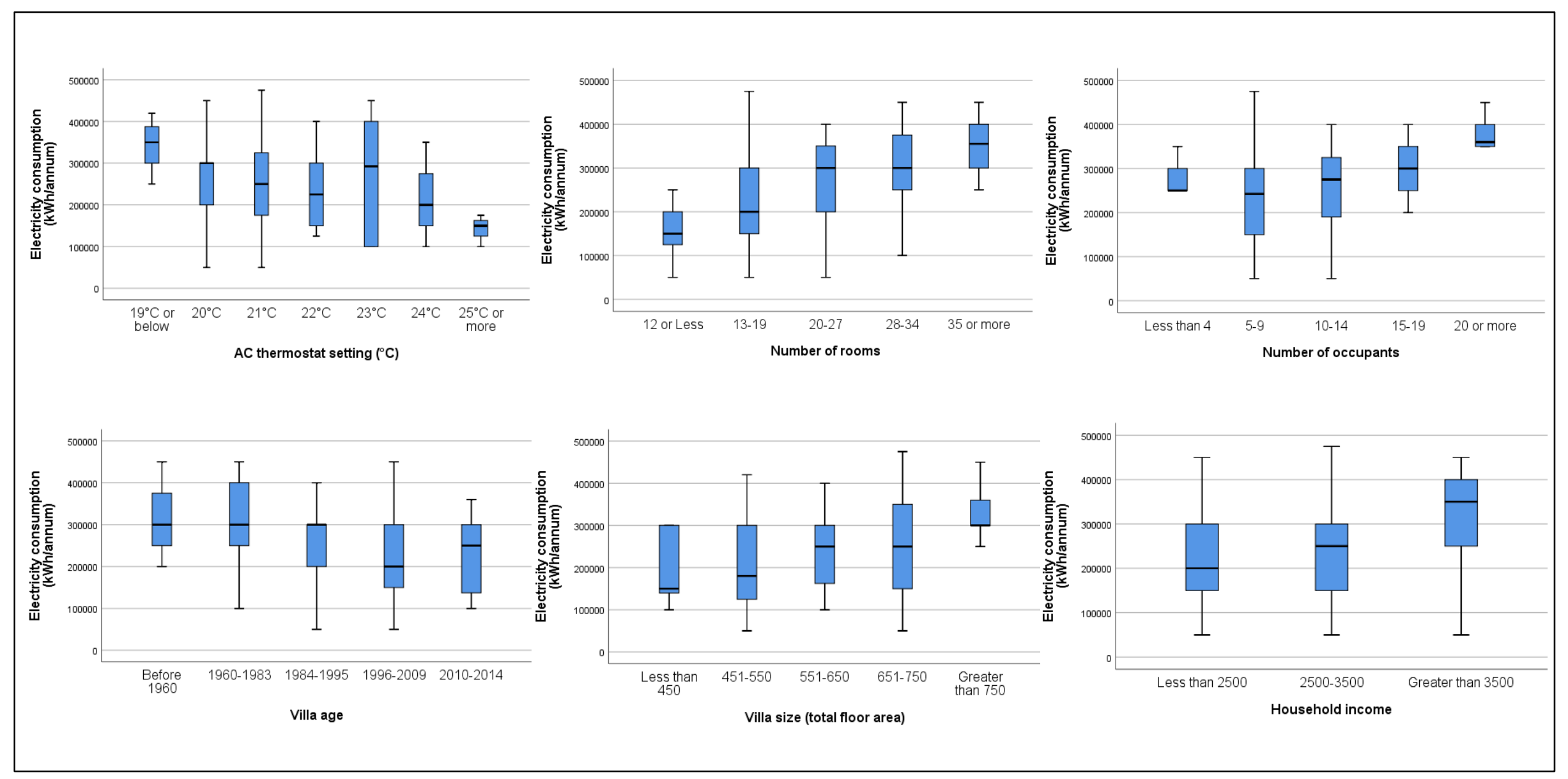

Figure 4 - Box plots of electricity consumption and different variables measured

Note: electricity consumption data with outliers removed (101 responses) 
A regression model was then run, for both sets of electricity consumption data (with and without outliers). The model was significant for both data sets when accounting for AC thermostat temperature setting, number of rooms, and number of occupants; for electricity data with outliers $R^{2}=0.12$, and for electricity data without outliers $R^{2}=0.32$. For the data set with outliers removed, the variables explained a greater degree of the variance in energy consumption, presumably because this data falls within the national consumption range. The adjusted $R^{2}=0.28$, which is close to $R^{2}$, indicating that the model generalizes fairly well. It is likely that a greater degree of the variability in energy may have been explained if real metered energy consumption data was used. However as the purpose of this survey is indicative rather than predictive, findings nonetheless provide valuable initial insight into potential energy use drivers that can be examined in future studies.

The coefficients of the regression equations (unstandardized betas) indicate the relationship between energy use and each predictor variable as well and the degree to which each predictor affects the outcome (if all other predictors are held constant). For every 1 degree rise in thermostat temperature setting, energy use decreases by $22,006 \mathrm{kWh} /$ annum (approximately 10\%) if household size and number of occupants remain constant. The relative contribution of each predictor variable in influencing energy use was further illustrated with the standardized betas. All predictor variables significantly contribute to the model, with thermostat temperature setting having the greatest impact on energy use, followed by the number of rooms and number of occupants (table 11).

Table 11 - Linear model of predictors of electricity consumption

\begin{tabular}{|c|c|c|c|c|c|c|}
\hline & \multicolumn{2}{|c|}{ Unstandardized coefficients } & $\begin{array}{c}\text { Standardized } \\
\text { coefficients }\end{array}$ & \multicolumn{2}{c|}{ Significance } & Collinearity \\
\cline { 2 - 7 } & B & SE B & Beta & t- statistic & P-value & VIF \\
\hline Constant & $220,582.46$ & 35411.49 & - & & 0.000 & - \\
\hline $\begin{array}{c}\text { AC thermostat } \\
\text { temperature setting }\end{array}$ & $\begin{array}{c}-22,005.70 \\
(-34,082.67,-99,28.74)\end{array}$ & 6048.87 & -0.378 & -3.64 & 0.001 & 1.04 \\
\hline $\begin{array}{c}\text { Number of rooms } \\
29,46.26\end{array}$ & 1193.60 & 0.274 & 2.47 & 0.016 & 1.19 \\
\hline $\begin{array}{c}\text { Number of } \\
\text { occupants }\end{array}$ & $\begin{array}{c}44,98,5,329.36) \\
(593.55,8,404.24)\end{array}$ & 1956.03 & 0.258 & 2.33 & 0.025 & 1.22 \\
\hline
\end{tabular}

Note: $R^{2}=0.316$; adjusted $R^{2}=0.284$, Durbin Watson $=1.981$

$95 \%$ confidence intervals for $B$ reported in parentheses.

To detect the presence and assess the impact of bias due to outliers in the model residual statistics were analysed by checking casewise diagnostics and model assumptions. The values on Cook's Distances all lie well below 1 indicating that no single case is affecting the model as a whole. Only $2 \%$ of the cases have a large Mahalanobis distance over 15 (cases have a mean distance of 3 ), and no case is beyond 2.5 standard residuals. The covariance ratio and DFBeta statistics were also observed and no cases have a notable influence on the regression parameters (DFBeta were all less than 1 and covariance ratios were within the calculated boundaries of 1.12 and 0.88 ).

Similarly, the assumption of independence of residuals is met as no serial correlation is detected between residuals and the Durbin Watson value of 1.981 is very close to 2 . All the Variance Inflation Factors (VIF) are less than 5 indicating non-existence of mulitcollinearity (correlations) between independent variables. The assumption of normality has also been met and the Kolmogorov Simrnov test showed normality to residuals $(P$-value $=0.20)$. The assumptions of linearity 
(between dependant and independent variables) and homoscedacity (equal variance between data values for dependent and independent variables) are also satisfied as scatter plots of standardised residuals against standardised predicted values revealed no major problems with outliers. 


\section{Discussion}

This study provides initial insights into the determinants of energy use in a sample of Kuwaiti villas and their relative importance. Primarily, findings show the importance of behaviour and building occupants as drivers of energy use. Although previous studies [7, 8, 20,23, 25] indicate that building physical characteristics such as size and type are relatively more important contributors, the analysis has indicated that an occupant driven cooling behaviour (AC thermostat temperature set points) is the most significant driver of energy use in villas. The effect of this behaviour is likely to be accentuated by the prevalence and heavy use of centralized cooling within large villas with many rooms. The role of temperature set points on the variation in energy use has been reported in a number of studies worldwide $(13,20,22,29,34]$. Steemers and Young Yun [22] have specifically noted that the effect of behaviour on cooling energy in air-conditioned buildings is considerably greater than on heating energy. Other variables measuring occupant behaviour such as $A C$ maintenance schedules, AC control during periods of prolonged absence, lighting control, winter heating, and thermal comfort control did not have statistically significant relationships with energy consumption in this study and were not significant predictors of this. In part, this could be due to the complexity associated with measuring occupant behaviour through surveys and analyzing this data through statistical methods such as regression, as indicated in past studies $[7,43]$. Nonetheless, descriptive analysis has revealed key findings about occupant behaviour likely to be contributing to wasteful consumption, and which can be examined in future studies. This includes a tendency among households to leave the cooling switched on during months of the year when external temperature is moderate, or when the villa is unoccupied for prolonged periods.

The number of occupants (a socio-demographic factor) is also found to be a significant predictor of energy use in the regression analysis, in line with findings from other studies [7, 32, 33]. With regards to household income however, although a positive correlation was found with energy use as in other studies $[20,28,31]$, such a variable was not a significant predictor in the regression analysis. The income effect is minimal presumably because low electricity tariffs are allowing lower income households to afford higher levels of energy use. Other socio-demographic factors such as employment status, education status, and occupant age did not have statistically significant relationships with energy use.

With regards to building physical factors, the regression analysis found that the number of rooms compared to the total floor area (in $\mathrm{m}^{2}$ ) statistically explained a significant amount of the variability in energy use. The number of rooms is believed to be a more accurate measure of dwelling size in this survey because of its numerical form (compared to floor area measured in rank order level), and the likelihood that occupants are more aware of how many rooms they have rather than their villa size (in $\mathrm{m}^{2}$ ). Villa age (initially measured under 6 categories) was found to have a relatively weak negative correlation with energy consumption indicating that although newer villas tend to consume less energy than older ones (presumably because of improved insulation and glazing), the effect is minimal. To further determine the effect of the 1983 energy conservation code villa age was transformed into a dichotomous variable (pre and post 1983) in the regression analysis. Findings however show that this did not significantly explain the variance in energy use, indicating 
that the effect of improved fabric efficiency is possibly being diluted by factors such as poor code implementation and an increase in building size and appliance use with time.

In line with other studies $[7,20]$, the regression model has shown that a greater degree of the variability in energy consumption can be explained when combining both physical and occupant related variables. Although only $31.6 \%$ of the variability in energy use was explained, this is deemed reasonable given the complexity associated with household energy use and the current understanding of this, as well as the quality of the reported energy data used in the regression analysis. Previous research has indicated that even when all variables assessing a range of predictor types are used, just under half of the variability in domestic energy use can be explained [7].

\section{Conclusions}

This paper presents the findings of a household survey undertaken with the aim of identifying key drivers of energy use in Kuwaiti villas. While many countries have researched their building energy use in considerable detail including the collection of robust energy use data, there are many other countries, such as Kuwait, where little effort has been placed into collecting reliable statistics about the built stock and its energy use. This study has attempted, within cultural constraints, to undertake such a survey, collecting information on both the physical and social characteristics of buildings from a sample of 250 homes throughout the six districts of Kuwait.

Survey findings have a number of important implications for policy makers. They indicate the importance of considering both the physical and occupant related characteristics of homes when examining residential energy use and designing interventions. In Kuwait, the significant effect of AC thermostat set points is likely to be emphasized by the predominance of large villas (with many rooms, several of which unused) that are centrally cooled throughout. Therefore a policy intervention promoting a reduction in villa size (to suit the number of occupants and their needs) is likely to result in a significant decrease in the demand for central cooling and thus overall residential energy consumption. Similarly imposing AC maintenance and replacement schemes could deliver potential energy savings, particularly as findings indicate most households have fairly old AC units, many of which are not routinely maintained. It is also recommended that policy makers consider electricity tariff redesigns as well as robust bill payment structures (i.e quarterly per annum), both of which are likely to have a significant effect on occupant energy practices, high space use, AC control, and energy consumption awareness.

The survey has also sought to determine the impact of the MEW's 1983 energy conservation code by asking respondents about their villa's age (a proxy for fabric efficiency), fabric insulation and glazing. Although the effect of insulation and glazing could not be fully assessed from survey data, a trend towards better levels of insulation and double glazing was found among newer villas, which also tended to have lower energy consumption than those built before the 1983 code. However, the weak negative correlation detected between villa age and energy consumption indicates that although newer villas may consume less energy, the effect is minimal due possibly to poor code implementation and an increase in building size with time. To better inform interventions in this field, a more detailed examination of fabric efficiency is needed. It is also valuable to determine whether Kuwait Municipality building codes, which have allowed for an increase in building size with 
time, are counteracting the efficiency effects imposed by the MEW's energy conservation code. This would provide valuable insight on whether policy goals from different government agencies are in alignment.

Finally, this study has highlighted the challenges that are faced when relying on solely collecting occupants' perceptions of energy use and demonstrates the importance of such studies utilising verification of occupant perceptions of energy use and building size with measured data. Although measured data is difficult to acquire due to technical, cost, and data privacy concerns, such issues need to be overcome and countries need to be prepared to considerably invest in detailed long term longitudinal studies of energy use in buildings to effectively inform policy development in this field.

\section{Further work}

Although survey findings have provided important insights, such findings are indicative and further investigation and research is essential. A survey of a larger random sample of villas using actual metered energy data is needed to obtain results that are more generalizable to the wider stock or population of villas in Kuwait. . Similarly, given the complex nature of residential energy demand, the authors of this paper are currently exploring key energy use drivers through an investigative case study strategy. This strategy involves a more in-depth examination of a number of villas within their natural settings for a period of one year. The investigation draws on multiple sources of data, including document analysis, occupant interviews, and indoor environmental monitoring to allow for the triangulation of findings and a better understanding of the interaction between building physical and social energy use drivers.

\section{Acknowledgements}

This study was undertaken as part of a PhD research at the UCL Energy Institute. Oreszczyn is Director of the RCUK Centre for Energy Epidemiology at UCL and funded by Research Councils UK (EP/K011839/1). The authors are grateful to all the participants in the household survey and to the interview personnel for their generous assistance in the data collection process. The authors are also grateful to the Kuwait Ministry of Electricity and Water for their data and information support. 


\section{References}

[1] Lahn, G., Stevens, P., and Preston, F., Saving oil and gas in the Gulf. London: A Chatham House Report. 2013 http://www.chathamhouse.org/publications/papers/view/193884

[2] Ministry of Electricity and Water (MEW), Statistical data book 2012 - Electricity and water, 2012

[3] Alshalfan, S., The right to housing in Kuwait: An urban injustice in a socially just system, Kuwait programme on development, governance and globalization in the Gulf states, LSE, London, 2013.

http://www.Ise.ac.uk/government/research/resgroups/kuwait/documents/The-right-to-housing-inKuwait.pdf

[4] Krane, J., 2013. Stability versus sustainability: Energy policy in the gulf monarchies. Electricity policy research group working paper 1302, Cambridge working paper in Economics 1304. University of Cambridge

[5] Oxford Business Group, The Report - Kuwait 2015 www.oxfordbusinessgroup.com/country/Kuwait

[6] Wood, M., and Alsayegh, O., Impact of oil prices, economic diversification policies, and energy conservation programs on the electricity and water demands in Kuwait, Energy Policy, 66 144-156, 2014

[7] Huebner, G.M, Hamilton, I., Chalabi, Z., Shipworth, D., Oreszczyn, T., Explaining domestic energy consumption-The comparative contribution of building factors, socio-demographics, behaviours and attitutes. Applied Energy, 159, pp.589-600,2015

[8] Kavousian, A., Rajagopal, R., and Fischer, M., Determinants of residential electricity consumption: using smart meters to examine the effect of climate, building characteristics, appliance stock, and occupants' behaviour. Energy, 55, pp.184-194, 2013

[9] Howden-Chapman, P., Viggers, H., Chapman R., O’Dea, D., Free, S., O'Sullivan, K., Warm homes: Drivers of the demand for heating in the residential sector in New Zealand. Energy Policy, 37,pp.3387-3399, 2009

[10] Maheshwari, G.P., Al-Mulla, A., and Al-Hadban, Y., Energy management program for the state of Kuwait. International Journal of Energy Technology and Policy, 7 (1), pp. 95-112, 2009

[11] Alotaibi, S., Energy consumption in Kuwait: prospects and future approaches. Energy Policy, 39, pp.6376432011.

[12] Kuwait Central Administration for Statistics, 2013, Income and Expenditure statistical report. Central Statistical Bureau. www.alqabas.com.kw/node/905575

[13] Al-Mumin, A., Khattab, O., Sridhar, G., Occupants' behaviour and activity patterns influencing the energy consumption in the Kuwaiti residences. Energy and Buildings, 35, pp.549-559, 2003.

[14] Hertog, S., and Luciani, G., Energy and sustainability in the GCC. Kuwait programme on development, governance and globalization in the Gulf states, LSE, London, 2009 http://www2.Ise.ac.uk/government/research/resgroups/kuwait/documents/Hertog\%20paper.pdf

[15] Ministry of Electricity and Water (MEW), Energy conservation program: Code of practice. Kuwait, 2014

[16] Public Authority for Civil Information (PACl), Housing and Building Statistics, 2013, http://www.paci.gov.kw/en/

[17] Ministry of Electricity and Water (MEW), Residential sector energy consumption 2009, Information centre and statistics department, Kuwait. 2014

[18] Department of Energy and Climate Change (DECC), Energy consumption in the UK 2014, 2014 https://www.gov.uk/government/uploads/system/uploads/attachment data/file/338662/ecuk chapter 3 domestic factsheet.pdf

[19] Department of Energy and Climate Change (DECC), National energy efficiency data framework, June 2013, 
https://www.gov.uk/government/uploads/system/uploads/attachment data/file/209089/National Energ y Efficiency Data-framework June 2013 Part I.pdf

[20] Guerra Santin,O., Itard, L., and Visscher H., The effect of occupancy and building characteristics on energy use for space and water heating in Dutch residential stock. Energy and Building, 41, pp.1223-1232,2009

[21] Leth-Petersen, S., Togeby M., Demand for space heating in apartment blocks: measuring effect of policy measures aiming at reducing energy consumption, Energy Economics, 23, pp.387-403 62

[22] Steemers K., and Young Yun, G., Household energy consumption: a study of the role of occupants. Building Research and Information, 37 (5-6), pp.625-37, 2009

[23] Kelly, S., Do homes that are more energy efficient consume less energy? A structural equation model of the English residential sector. Energy, 36 (9), pp.5610-5620, 2011

[24] Yohanis YG, Mondol JD., Wright A, Norton, B., Real-life energy use in the UK: how occupancy and dwelling characteristics affect domestic electricity use. Energy and Building, 40(6), pp.1053-1059

[25] Theodoridou I., Papadopoulos AM, Hegger M, Statistical analysis of the Greek residential building stock. Energy and Building, 43(9), pp.2422-2428, 2011

[26] Liao, HC, Chang TF. Space-heating and water-heating energy demands of the aged in the US. Energy Economics, 24, pp.267-84, 2002

[27] Chiu, L.F., Lowe, R., Raslan, R., Altamirano-Medina, H., Wingfield, J., 2014, A socio-technical approach to post-occupancy evaluation: interactive adaptability in domestic retrofit. Building Research \& Information, 42 (5), pp. 574-590

[28] Abrahamse, W., Steg, L., How do socio-demographic and psychological factors relate to households direct and indirect energy use and savings? Journal of Economic Psychology , 30, pp.711-720, 2009

[29] Haas, R., Auer, H., and Biermayr, P., The impact of consumer behaviour on residential energy demand for space heating, Energy and Buildings, 27, pp.195-205,1998

[30] Papakosta, K.T., Sotiropoulos, B.A., Occupational and energy behaviour patterns in Greek residences, Energy and Buildings, 26, pp. 207-213, 1997

[31] Biesiot, W., Noorman, Energy requirements of household consumption: a case study of NL, Ecological Economics, 28, pp.367-383, 1999

[32] Druckman, A., Jackson T., Household energy consumption in the UK: a highly geographically and socioeconomically disaggregated model. Energy Policy, 36, pp.3177-3192, 2008

[33] Brandon, G., Lewis, A., Reducing household energy consumption: a qualitative and quantitative field study. Journal of Environmental Psychology, 19, pp.75-85, 1999

[34] Linden, A.L., Carlsoon-Kanyama, A, Eriksoon, B., Efficient and inefficient aspects of residential energy behaviour:what are the policy instruments for change?, Energy Policy, 34, pp.1918-1927, 2006

[35] Gatersleben, B., Steg, L., Vlek, C., measurement and determinants of environmentally significant consumer behaviour. Environmental Behaviour, 34 (3), pp. 335-362, 2002

[36] Kevin Lomas,K., Oreszcyn, T., Shipworth, D., Wright, A., and Summerfield, A., Carbon Reduction in Buildings (CaRB) - Understanding the social and technical factors that influence energy use in UK homes. http://discovery.ucl.ac.uk/2302/1/2302.pdf

[37] Energy Follow-up Survey, 2011, Report 11 - Methodology, Prepared by BRE on behalf of the Department of Energy and Climate Change. December 2013. BRE report number 288851. https://www.gov.uk/government/uploads/system/uploads/attachment data/file/274780/11 Methodolo gy.pdf

[38] Sweetman, T., Al-Ghaithi, H., Almaskari, B., Calder, C., Gabris, J., Patterson, M., Megdi Mohaghegh, S., Oreszczyn, T., Raslan, R., Residential Energy Use In Oman: A Scoping Study. Project Report, 13th January 2014 - Version 8

http://discovery.ucl.ac.uk/1425280/1/Oman\%20Final\%20Report\%20v0\%208 revised.pdf 
[39] U.S. Department of Energy, Energy Information Administration, Residential Energy Consumption Survey, Household Questionnaire, 2009. https://www.eia.gov/survey/form/eia 457/form.pdf

[40] Smithson, M., 2003. Confidence Intervals. Sage

[41] IBM SPSS Statistics for Windows, Version 22.0. IBM Corp. Released 2013. Armonk, NY: IBM Corp.

[42] Kuwait Metrological Center, n.d. Climate data. State of Kuwait Directorate General of Civil Aviation, Metrological Department. Data from 1964-2015.

[43] Shipworth, D., Synergies and conflicts on the landscape of domestic energy consumption: beyond metaphor". Proceedings of the $7^{\text {th }}$ European Council for an Energy Efficient Economy Summer Study, 30 May-4 June, Mandelieu France, 2005 